Article

\title{
Design of Thermochromic Polynorbornene Bearing Spiropyran Chromophore Moieties: Synthesis, Thermal Behavior and Dielectric Barrier Discharge Plasma Treatment
}

\author{
Saleh A. Ahmed ${ }^{1,2, *}$, Rawda M. Okasha ${ }^{3}$, Khalid S. Khairou ${ }^{2}$, Tarek H. Afifi ${ }^{3}$, \\ Abdel-Aleam H. Mohamed ${ }^{4,5}$ and Alaa S. Abd-El-Aziz ${ }^{6}$ \\ 1 Chemistry Department, Faculty of Applied Sciences, Umm Al-Qura University, Makkah 21955, Saudi Arabia \\ 2 Chemistry Department, Faculty of Science, Assiut University, Assiut 71516, Egypt; kskhairou@uqu.edu.sa \\ 3 Chemistry Department, Faculty of Science, Taibah University, Al-Madinah Al-Munawarah 30002, \\ Saudi Arabia; rokasha@taibahu.edu.sa (R.M.O.); tmahmoud@taibahu.edu.sa (T.H.A.) \\ 4 Physics Department, Faculty of Science, Taibah University, Al-Madinah Al-Munawarah 30002, Saudi Arabia; \\ amohammedb@taibahu.edu.sa \\ 5 Physics Department, Faculty of Science, Beni-Suef University, Beni-Suef 62511, Egypt \\ 6 Chemistry Department, Faculty of Science, University of Prince Edward Island, Charlottetown, PE C1A 4P, \\ Canada; abdelaziz@upei.ca \\ * Correspondence: saleh_63@hotmail.com; Tel.: +966-53-043-5760
}

Received: 18 October 2017; Accepted: 16 November 2017; Published: 22 November 2017

\begin{abstract}
A new class of thermochromic polynorbornene with pendent spiropyran moieties has been synthesized. Functionalization of norbornene monomers with spirobenzopyran moieties has been achieved using Steglich esterification. These new monomeric materials were polymerized via Ring Opening Metathesis Polymerization (ROMP). In spite of their poor solubility, polynorbornenes with spirobenzopyran exhibited thermochromic behavior due to the conversion of their closed spiropyran moieties to the open merocyanine form. Moreover, these polymers displayed bathochromic shifts in their optical response, which was attributed to the J-aggregation of the attached merocyanine moieties that were associated with their high concentration in the polymeric chain. The surface of the obtained polymers was exposed to atmospheric pressure air Dielectric Barrier Discharge (DBD) plasma system, which resulted in the reduction of the surface porosity and converted some surface area into completely non-porous regions. Moreover, the plasma system created some areas with highly ordered J-aggregates of the merocyanine form in thread-like structures. This modification of the polymers' morphology may alter their applications and allow for these materials to be potential candidates for new applications, such as non-porous membranes for reverse osmosis, nanofiltration, or molecular separation in the gas phase.
\end{abstract}

Keywords: polynorbornene; thermochromic; spiropyran; J-aggregation; ROMP; DBD plasma; SEM images

\section{Introduction}

Chromogenic polymers are a significant class of smart materials that have been under investigation over the past decade [1-6]. The key feature of these materials is their quick and reversible responses to external stimuli. Among these chromogenic materials, photochromic and thermochromic behavior has been observed in various classes of molecules, such as liquid crystals and polymer incorporating smart moieties [1-6]. Currently, there is progress in the development of thermochromic polymers 
as promising candidates for emerging areas, such as smart windows, biological sensors, and intelligent packaging.

The thermochromic effect can be introduced to the polymeric systems via incorporation of thermochromic leuco dye into the polymer chains $[7,8]$. Examples of these dyes include spirolactones, fluorans, spirooxazine, and spiropyran leuco dyes [1,3-5,9]. Spiropyran, as a family of photochromic and thermochromic materials, have been known for their inter-conversion from a closed form (SP) into an open merocyanine (MC) form upon irradiation with UV-light. There are advantages of these molecules that include high efficiency of photoisomerizations, sufficient thermal stability of both the open and the closed forms, and a very high resistance to photofatigue [10-18]. Spiropyran also has an impressive capability of isomerization by several other independent stimuli, such as temperature [10] (thermochromism), pH [11-13] (acidochromism), solvent polarity [14] (solvatochromism), redox potential [15] (electrochromism), metal ions [16,17], and even mechanical force [18] (mechanochromism).

Spiropyran has been merged into different classes of polymeric materials. For instance, homopolymers, random copolymers, and block copolymers containing spiropyran were synthesized via polymerization of monomeric units containing spiropyran motif using ring-opening metathesis polymerisation (ROMP) [19,20], AIBN-initiated free radical polymerisation of terminal alkenes [21-27], or by polycondensation reactions [28-31] and atom transfer radical polymerization (ATRP) [32-34] or reversible addition-fragmentation transfer (RAFT) polymerization [35-37]. Meanwhile, spiropyran has also been grafted on pre-formed polymers like polytetrafluoroethylene (PTFE) [38], polyaniline [39], polyacrylates [40-42], polysulfones [43,44], and polyphosphazenes [45].

Even though there are few examples of spiropyran functionalized polynorbornene reported in the literature as photochromic macromolecules $[19,20]$, this class of macromolecules still requires further investigation in order to have a better understanding of the influence of the spiropyran moiety on the performance of the polymer chains, especially as thermochromic materials. For instance, Hauser et al. reported the synthesis of photochromic norbornene homo- and copolymers with spiropyran moieties [19]. The authors faced some difficulties in obtaining the homopolymer in good yields due to the formation of the opened merocyanine form. On the other hand, their copolymers were quite successful [19]. Unlike all of the previous reports that illustrated the synthesis of polynorbornene containing spiropyran as photochromic systems [19,20], this work is the first example of exploring the thermochromic behavior of polynorbornene bearing spiropyran switches.

Ring opening metathesis polymerization (ROMP) of norbornene monomers has been a very successful approach to control the polymer's molecular structure, size, and bulk properties [46-53]. In the past, we have used Grubbs catalyst in the synthesis of various substituted polynorbornenes [54-61]. We also developed several series of polynorbornene containing aryl- and hetaryl-azo chromophores as candidates for long-term storage information, as well as in photonic devices [62]. Our previous work has also been dedicated to the synthesis of various classes of chromogenic molecules containing a spiro carbon, such as benzopyrans, oxazines, and dihydroindolizines, which are appropriate chemosensors that respond to external stimuli, including temperature [63-70].

This article will shed more light on the synthesis, characterization, and unexpected thermochromic properties of polynorbornenes containing spiropyran species using ROMP. These polymeric materials displayed thermochromic behavior due to the cleavage of the spiro $\mathrm{C}-\mathrm{O}$ bond and forming the zwitterionic merocyanine form. This class of polymers is well known for its high surface porosity, which suits plenty of applications, such as smart windows, tunable light filters, large-area displays, as well as sensors that can visualize local surface temperatures $[19,20,71]$.

Modification of a polymer's morphology is a key feature of controlling its properties while maintaining its adequate bulk properties [72-75]. Surface modification of polymeric materials is one of the most attractive topics in the literature, which conjures the possibilities of a new era of applications and enhances the performance of these materials. Modification of the polymeric surface can be obtained using various approaches, such as flame, corona discharge, plasma, photons, electron beam, 
ion beam, X-ray, and $\gamma$-ray [72-75]. The use of a plasma system is a versatile and successful strategy for modifying the surface properties or introducing desired chemical groups at the surface of a polymer without affecting its bulk properties [72-75]. In this study, the surface of the obtained polymers has been subjected to an atmospheric pressure air Dielectric Barrier Discharge (DBD) plasma system in order to examine its effects on the polymers' morphology. Modification of the surface character of the desired polymers allowed for these materials to be potential candidates for new applications, such as non-porous membranes for reverse osmosis, nanofiltration, or molecular separation in the gas phase.

\section{Materials and Methods}

\subsection{Materials and Characterization}

\subsubsection{General}

All of the chemicals were available from Sigma-Aldrich Chemical Co. (Taufkirchen, Germany) and were used without further purification. Solvents were high performance liquid chromatography (HPLC) grade. ROMP was performed in anhydrous dichlormethane (DCM) $>99.8 \%$ containing amylene as stabilizer. ${ }^{1} \mathrm{H}$ NMR and ${ }^{13} \mathrm{C}$ NMR spectra were recorded at 400 and $100 \mathrm{MHz}$, respectively, on Bruker $400 \mathrm{MHz}$ ultrashieldTM NMR spectrometer (Bruker, Fällanden, Switzerland), with chemical shifts calculated in $\mathrm{Hz}$, referenced to solvent residues. The IR spectra of the new compounds were recorded on a Jasco FTIR-300 E Fourier Transform Infrared Spectrometer (Jasco, Tokoyo, Japan). Thermogravimetric analysis (TGA) of the polymeric materials was carried out under nitrogen atmosphere at a heating rate $10^{\circ} \mathrm{C} \cdot \mathrm{min}^{-1}$ using TA instrument, model SDT600 (New Castle, DE, USA). Differential Scanning Calorimeter (DSC) measurements were performed using a q2000 apparatus with T zero ${ }^{\circledR}$ techniques from TA instruments (New Castle, DE, USA). The morphological features of the polymers were determined using a "Shimadzu XRD-6000" computerized diffractometer (Shimadzu, Tokoyo, Japan), which consists of $\alpha$-pw1400/90 stabilized X-ray generator, $\alpha$-pw1050/70 vertical goniometer, $\alpha$-pw1995/60 proportional counter, and $\alpha$-pw1930 electronic panel. Nickel-filter copper radiation with $\lambda=1.541 \AA$ was used in this investigation. Scanning Electron Microscope (SEM) measurements have been performed using SEM Model Philips XL 30 (FEI company, Hillsboro, OR, USA) with accelerating voltage $30 \mathrm{KV}$, magnification $10 \times$ up to $4000 \times$, and resolution for $\mathrm{W}$. The obtained polymers have been heated up to $180^{\circ} \mathrm{C}$ and then cooled to room temperature either as dry or wet sheets. Wettability has been tested in dichloromethane, dimethyl formamide, methanol, chloroform, and aqueous solution.

\subsubsection{Dielectric Barrier Discharge (DBD) Plasma System}

An atmospheric air-dielectric barrier discharge DBD system was used to generate atmospheric pressure plasma in air [76]. The plasma system consists of two parallel metallic electrodes (the copper cylinder and the stainless steel disc) separated by a $3 \mathrm{~mm}$ gape. The upper copper electrode has about a $40 \mathrm{~mm}$ diameter and was covered on the bottom by a $2 \mathrm{~mm}$ thick dielectric quartz sheet $60 \times 60 \mathrm{~mm}$. A high voltage power-supply was connected to the upper electrode, while the lower electrode was grounded. The high voltage electrode was surrounded by a Teflon sleeve for operator safety. The power supply generated sinusoidal waveform signal of $23 \mathrm{kV}$ and $25 \mathrm{kHz}$. The current and voltage waveforms were recorded using DPO7354 C - 3.5 GHz-Tektronix oscilloscope (Tektronix Inc., Beaverton, OR, USA) with a person probe model: 6585 and P6015A -1:1000 Tektronix-high voltage probe, respectively. The treated samples were placed between the two electrodes on the lower stainless steel electrode. Plasma images were captured by Nikon digital camera D3200 (Nikon, Thailand) with AF-S Micro NIKKOR 105 mm lens. 


\subsection{Synthesis of the Target Spirobenzopyrans and Their Polymerization with Norbornene Moiety}

\subsubsection{Synthesis of $1^{\prime}, 3^{\prime}, 3^{\prime}$-Trimethyl-6-nitrospiro[chromene-2,2'-indoline]-5'-carboxylic Acid (4)}

In three necked flask connected with inlet dry argon, a mixture of 1,3,3-trimethyl-2-methylene5-carboxy-3H-indole (1150 mg, $5 \mathrm{mmol})$ and 2-hydroxyl-5-nitrobenzaldehyde (970 mg, $6 \mathrm{mmol}) \mathrm{in}$ freshly distilled THF (100 mL) was heated under reflux and argon for $10 \mathrm{~h}$. The mixture was cooled down in an ice bath, and the resulting precipitate was filtered off. The pure product was obtained after column chromatography on silica gel using DCM as eluent $\left(R_{\mathrm{f}}=0.32\right)$ to yield the chromophore I as a pale yellow powder in (460 mg, 24\%). ${ }^{1} \mathrm{H}$ NMR (400 MHz, DMSO-d $) 1.13\left(\mathrm{~s}, 3 \mathrm{H}, \mathrm{CH}_{3}\right), 1.24(\mathrm{~s}, 3 \mathrm{H}$, $\left.\mathrm{CH}_{3}\right), 2.76\left(\mathrm{~s}, 3 \mathrm{H}, \mathrm{N}-\mathrm{CH}_{3}\right), 6.02(\mathrm{~d}, 1 \mathrm{H}, J=10 \mathrm{~Hz}), 6.70(\mathrm{~d}, 1 \mathrm{H}, J=8 \mathrm{~Hz}), 6.92(1 \mathrm{H}, \mathrm{d}, 9 \mathrm{~Hz}), 7.26(1 \mathrm{H}, \mathrm{d}$, $10 \mathrm{~Hz}), 7.69(1 \mathrm{H}, \mathrm{d}, 8 \mathrm{~Hz}), 7.81(1 \mathrm{H}, \mathrm{dd}, 2$ and $8 \mathrm{~Hz}), 8.02(1 \mathrm{H}, \mathrm{dd}, 3$ and $9 \mathrm{~Hz}), 8.24(1 \mathrm{H}, \mathrm{d}, 3 \mathrm{~Hz}), 12.39$ $(1 \mathrm{H}, \mathrm{s}, \mathrm{COOH}) ;{ }^{13} \mathrm{C}$ NMR $\left(100 \mathrm{MHz}, \mathrm{DMSO}-d_{6}\right) \delta 19.9,25.9,28.9,51.9,106.4,106.6,116.0,119.4,121.4$, $122.2,123.4,123.4,126.4,129.1,131.4,136.4,141.3,151.7,159.4,167.9$.

\subsubsection{Synthesis of 3-(3',3'-Dimethyl-6-nitrospiro[chromene-2,2'-indolin]-1'-yl)propanoic Acid (5)}

Under an argon atmosphere, a mixture of 1-(2-carboxyethyl)-2,3,3-trimethyl-3H-indol-1-ium bromide (311 mg, $1 \mathrm{mmol}$ ) and (167 g, $1 \mathrm{mmol}$ ) 2-hydroxy-5-nitrobenzaldehyde was added to $100 \mathrm{~mL}$ dry ethyl methyl ketone in the presence of triethyl amine $(1 \mathrm{~mL})$, followed by heating under reflux in the dark for $24 \mathrm{~h}$. After the removal of the solvent, the product was washed with ether and the pure product of chromophore 5 was obtained after column chromatography using ethyl acetate-cyclohexane ( $2: 8$ then $4: 6)$ as eluent $\left(R_{\mathrm{f}}=0.32\right)$. The resulting violet-red powder was recrystallized from ethanol to obtain $136 \mathrm{mg}$, for a $36.1 \%$ yield of yellow-brown powder. ${ }^{1} \mathrm{H}$ NMR $\left(400 \mathrm{MHz}, \mathrm{DMSO}-d_{6}\right) 1.09$ $\left(\mathrm{s}, 3 \mathrm{H}, \mathrm{CH}_{3}\right), 1.52\left(\mathrm{~s}, 3 \mathrm{H}, \mathrm{CH}_{3}\right), 2.35\left(\mathrm{~m}, 1 \mathrm{H}, \mathrm{CH}_{2}\right), 2.46\left(\mathrm{~m}, 1 \mathrm{H}, \mathrm{CH}_{2}\right), 3.38\left(\mathrm{~m}, 1 \mathrm{H}, \mathrm{N}-\mathrm{CH}_{2}\right), 3.48(\mathrm{~m}$, $\left.1 \mathrm{H}, \mathrm{N}-\mathrm{CH}_{2}\right), 6.00(\mathrm{~d}, 1 \mathrm{H}, J=10 \mathrm{~Hz}), 6.63(\mathrm{~d}, 1 \mathrm{H}, 10 \mathrm{~Hz}), 6.78(\mathrm{t}, 1 \mathrm{H}, J=8 \mathrm{~Hz}), 6.86(\mathrm{~d}, 1 \mathrm{H}, 10 \mathrm{~Hz})$, $7.11(\mathrm{~m}, 2 \mathrm{H}), 7.19(\mathrm{~d}, 1 \mathrm{H}, 10 \mathrm{~Hz}), 7.99(2 \mathrm{H}, \mathrm{dd}, 3$ and $9 \mathrm{~Hz}), 8.21(\mathrm{~d}, 1 \mathrm{H}, 2 \mathrm{~Hz}) ;{ }^{13} \mathrm{C} \mathrm{NMR}(100 \mathrm{MHz}$, DMSO- $\left.d_{6}\right) \delta 19.8,26.8,37.7,44.29,52.4,106.9,116.0,118.9,119.4,120.9,121.8,122.4,126.2,127.4,127.9$, $134.2,146.7,160.4$.

\subsubsection{Synthesis of Norbornene Monomers}

Exo, endo-5-norbornene-2-methanol (2 $\mathrm{mmol})$, chromophores 4 \& 5 (0.5 mmol), $\mathrm{N}$,N-dimethylaminopyridine $(244 \mathrm{mg}, 2 \mathrm{mmol})$ and $8 \mathrm{~mL}$ of $\mathrm{CH}_{2} \mathrm{Cl}_{2}$ were placed in a $50 \mathrm{~mL}$ round bottom flask. Dicyclohexylcarbodiimide (413 mg, $2 \mathrm{mmol}$ ) was dissolved in $2 \mathrm{~mL}$ of $\mathrm{CH}_{2} \mathrm{Cl}_{2}$ and added to the stirring mixture at $0{ }^{\circ} \mathrm{C}$. The reaction was carried out at room temperature under a nitrogen atmosphere for $18 \mathrm{~h}$. After the removal of the solvent, the crude product was extracted with $\mathrm{CH}_{2} \mathrm{Cl}_{2}$, washed with water, and dried over $\mathrm{MgSO}_{4}$. The solvent was removed and the resulting precipitate was then purified using silica column with hexane/ethyl acetate (8:2 then 6:4) solution, $\left(R_{\mathrm{f}}=0.45\right)$.

Monomer 7: ${ }^{1} \mathrm{H}$ NMR (400 MHz, acetone- $\left.d_{6}\right): \delta(\mathrm{ppm})=0.54(\mathrm{~d}, 1 \mathrm{H}, \mathrm{H} 3 \mathrm{n}(\mathrm{n})), 1.15\left(\mathrm{~s}, 3 \mathrm{H}, \mathrm{CH}_{3}\right), 1.23(\mathrm{~s}$, $\left.3 \mathrm{H}, \mathrm{CH}_{3}\right), 1.11-1.44$ (m, 4H, H7a(n), H7a(x), H7s(x), H3x(x)), 1.66-1.83 (m, 4H, H2x, H7s(n), H3x(n), H3n(x)), 2.14 (br. s, 1H, H2n), 2.75 (s, 3H, N-CH $), 2.83-2.95$ (m, 2H, H1x \& H4n), 3.10-3.13 (m, 1H, H4x), 3.26-3.29 (m, 1H, H1x), 3.39-3.49 (m, 1H, H1n), $3.76\left(\mathrm{t}, 1 \mathrm{H}\right.$, nor- $\left.\mathrm{CH}_{2} \mathrm{O}(\mathrm{n})\right), 3.94(\mathrm{t}, 1 \mathrm{H}$, nor- $\left.\mathrm{CH}_{2} \mathrm{O}(\mathrm{n})\right)$, $4.12\left(\mathrm{t}, 1 \mathrm{H}\right.$, nor- $\left.\mathrm{CH}_{2} \mathrm{O}(\mathrm{x})\right), 4.30\left(\mathrm{t}, 1 \mathrm{H}\right.$, nor- $\left.\mathrm{CH}_{2} \mathrm{O}(\mathrm{x})\right), 5.91$ (br. s, 1H, H6(n)), 5.96 (br. s, 1H, H6(x)), 6.01 (d, J = 9.0 Hz, 1H, Ar), 6.06 (br. s, 1H, H5(n)), 6.16-6.18 (m, 1H, H5(x), ), 6.69 (d, J = 9.0 $\mathrm{Hz}, 1 \mathrm{H}, \mathrm{Ar}), 6.84(\mathrm{~d}, J=9.0 \mathrm{~Hz}, 1 \mathrm{H}, \mathrm{Ar}), 7.24(\mathrm{~d}, J=9.0 \mathrm{~Hz}, 1 \mathrm{H}, \mathrm{Ar}), 7.68(\mathrm{~s}, 1 \mathrm{H}, \mathrm{Ar}), 7.85$ (d, J = 9.0 Hz, $1 \mathrm{H}, \mathrm{Ar}), 7.99(\mathrm{~d}, J=9.0 \mathrm{~Hz}, 1 \mathrm{H}, \mathrm{Ar}), 8.22(\mathrm{~s}, 1 \mathrm{H}, \mathrm{Ar})$. 
${ }^{13} \mathrm{C}$ NMR (100 MHz, DMSO- $\left.d_{6}\right) \delta$ 19.83, 25.78, $29.01\left(\mathrm{CH}_{3}\right), 28.75$ (C3(n)), 29.55 (C3(x)), 41.39 (C2(n)), $41.55(\mathrm{C} 2(\mathrm{x})), 41.88(\mathrm{C} 4(\mathrm{x})), 42.11(\mathrm{C} 4(\mathrm{n})), 43.28(\mathrm{C} 1(\mathrm{x})), 43.58(\mathrm{C} 1(\mathrm{n})), 44.90(\mathrm{C} 7(\mathrm{x})), 49.34(\mathrm{C} 7(\mathrm{n})), 51.93$ (Ar-C), 64.90 (nor- $\mathrm{CH}_{2} \mathrm{O}(\mathrm{n})$ ), 65.81 (nor- $\mathrm{CH}_{2} \mathrm{O}(\mathrm{x})$ ), 106.24, 106.74, 115.76, 119.14, 121.11, 121.23, 123.09, 123.28, 126.18, 128.99, 131.17 (Ar-C \& Ar-CH), 132.80 (C6(n)), 136.74 (C6(x)), 136.94 (C5(n)), 137.76 (C5(x)), 136.88, 141.13, 151.83, 159.30 (Ar-C), 166.06 (CO). IR (KBr): $1640 \mathrm{~cm}^{-1}$ (CO).

Monomer 8: ${ }^{1} \mathrm{H}$ NMR $\left(400 \mathrm{MHz}\right.$, acetone- $\left.d_{6}\right): \delta(\mathrm{ppm})=0.36-0.39(\mathrm{~m}, 1 \mathrm{H}, \mathrm{H} 3 \mathrm{n}(\mathrm{n})), 1.08\left(\mathrm{~s}, 3 \mathrm{H}, \mathrm{CH}_{3}\right)$, $1.20\left(\mathrm{~s}, 3 \mathrm{H}, \mathrm{CH}_{3}\right), 1.18-1.38$ (m, 4H, H7a(n), H7a(x), H7s(x), H3x(x)), 1.66-1.79 (m, 4H, H2x, H7s(n), H3x (n), H3n(x)), 2.15 (br. s, 1H, H2n), $2.50\left(\mathrm{~m}, 1 \mathrm{H}, \mathrm{CH}_{2}\right), 2.58-2.60(\mathrm{~m}, 1 \mathrm{H}, \mathrm{H} 1 \mathrm{x}), 2.69\left(\mathrm{~m}, 1 \mathrm{H}, \mathrm{CH}_{2}\right)$, 2.84 (br. s, $1 \mathrm{H}, \mathrm{H} 4 \mathrm{n}), 2.98\left(\mathrm{t}, 1 \mathrm{H}\right.$, nor- $\left.\mathrm{CH}_{2} \mathrm{O}(\mathrm{n})\right), 3.13-3.16(\mathrm{~m}, 1 \mathrm{H}, \mathrm{H} 4 \mathrm{x}), 3.22\left(\mathrm{~m}, 1 \mathrm{H}, \mathrm{N}-\mathrm{CH}_{2}\right), 3.38(\mathrm{~m}$, $4 \mathrm{H}, \mathrm{N}-\mathrm{CH}_{2}$ \& nor- $\mathrm{CH}_{2} \mathrm{O}(\mathrm{n}),(\mathrm{x})$ \& (x)), 3.30 (br. s, 1H, H1x), 3.51-3.56 (m, 1H, H1n), 5.87 (br. s, 1H, Ar), 5.89 (br. s, 1H, H6(n)), 5.97 (br. s, 1H, H6(x)), 6.01 (br. s, 1H, H5(n) \& H5(x)), 6.56 (d, J = 9.0 Hz, 1H, Ar), 6.74-6.78 (m, 2H, Ar), 7.01-7.10 (m, 4H, Ar), 7.93 (d, J = 9.0 Hz, 1H, Ar), 8.05 (s, 1H, Ar).

${ }^{13} \mathrm{C}$ NMR (100 MHz, DMSO- $\left.d_{6}\right) \delta$ 19.48, $25.65\left(\mathrm{CH}_{3}\right), 29.19(\mathrm{C} 3(\mathrm{n})), 31.41(\mathrm{C} 3(\mathrm{x})), 39.46\left(\mathrm{CH}_{2}\right), 41.05$ (C2(n)), 41.33 (C2(x)), $41.42(\mathrm{C} 4(\mathrm{x})), 41.75(\mathrm{C} 4(\mathrm{n})), 41.93\left(\mathrm{CH}_{2}\right), 42.88$ (C1(x)), $43.19(\mathrm{C} 1(\mathrm{n})), 46.01$ (C7(x)), 48.98 (C7(n)), 52.33 (Ar-C), 64.79 (nor- $\left.\mathrm{CH}_{2} \mathrm{O}(\mathrm{n})\right), 65.76$ (nor- $\left.\mathrm{CH}_{2} \mathrm{O}(\mathrm{x})\right), 106.33,115.19$ (Ar-CH), 118.56 (Ar-C), 119.13, 121.47, 121.53, 122.59, 125.42, 127.48, 128.13 (Ar-CH), 132.26 (C6(n)), 136.20 (C6(x)), 136.33 (C5(n)), 136.40 (C5(x)), 146.14, 159.03 (Ar-C), 168.54 (CO). IR (KBr): $1644 \mathrm{~cm}^{-1}$ (CO).

\subsubsection{Preparation of Polynorbornene Pendent Chromophore Units}

In a $10 \mathrm{~mL}$ round bottom flask, the functionalized monomer and $0.5 \mathrm{~mL}$ of distilled dichloromethane for every $100 \mathrm{mg}$ of monomer were combined and stirred under a nitrogen atmosphere. In a second flask, the catalyst $([\mathrm{M}] /[\mathrm{I}]=100 / 1)$ was dissolved in an equivalent amount of dichloromethane and was also purged with nitrogen. The catalyst solution was then added drop wise to the stirring monomer solution, at which time a black sticky solid began to collect on the sides and bottom of the flask. The reaction was stirred for 1-4 h during which time more solid formed. The polymerization was then terminated by the addition of ethyl vinyl ether, and stirred for 15-30 min. The crude polymer was washed with dichloromethane to remove any remaining monomer. The purified polymer was then collected via suction filtration as a reddish sheet.

\section{Results}

\subsection{Synthesis of the Chromophores}

The synthesis of compound 4 has been achieved via reaction of 2-hydroxyl-5-nitrobenzaldehyde 1 and 1,3,3-trimethyl-2-methylene-5-carboxy-3H-indole (2) in refluxed dry THF (Scheme 1). The crude product was isolated at $0{ }^{\circ} \mathrm{C}$ and purified through column chromatography using dichloromethane as eluent. Meanwhile, the condensation reaction of compound 1 with 1-(2-carboxyethyl)-2,3,3-trimethyl$3 \mathrm{H}$-indol-1-ium bromide (3) and triethylamine in dry ethyl methyl ketone led to the formation of 3-( $3^{\prime}, 3^{\prime}$-dimethyl-6-nitrospiro[chromene-2,2'-indolin]-1'-yl)propanoic acid (5) after further purification using column chromatography with ethyl acetate-cyclohexane as eluent.

The structure of chromophores 4 and 5 was confirmed using ${ }^{1} \mathrm{H}$ and ${ }^{13} \mathrm{C}$ NMR spectroscopy. As anticipated, the two spectra displayed some similarities. For example, the two methyl protons of both compounds appeared as singlet between 1.09 and $1.52 \mathrm{ppm}$, while the aromatic protons appeared as sets of doublets in the range of 6.00 and $8.24 \mathrm{ppm}$. Differentiation between the two spectra includes the presence of $\mathrm{N}-\mathrm{CH}_{3}$ of chromophore 4 at $2.76 \mathrm{ppm}$, while chromophore 5 exhibited two sets of multiplets corresponding to the methylene spacers. The $\mathrm{N}-\mathrm{CH}_{2}$ protons appeared as two multiplets at 3.38 and $3.48 \mathrm{ppm}$. Moreover, the carboxylic proton of 4 resonated downfield at $12.39 \mathrm{ppm}$. 


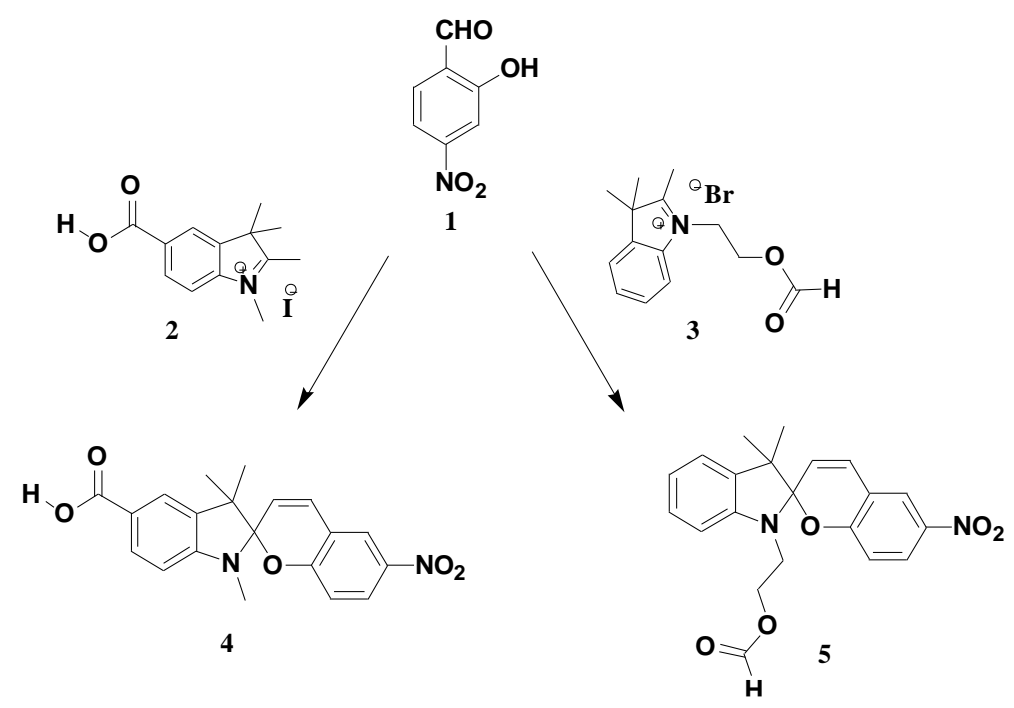

Scheme 1. Synthesis of spiropyran chromophores.

\subsection{Monomers Synthesis}

Functionalization of norbornene molecules with spiropyran chromophores was proceeded using Steglich esterification, as described in Scheme 2. Exo, endo-5-norbornene-2-mehanol (6) reacted with spiropyrans 4 and 5 in the presence of dicyclohexylcarbodiimide (DCC) and $N, N$-dimethylaminopyridine (DMAP) for $18 \mathrm{~h}$. Purification of the obtained monomers included extraction with $\mathrm{CH}_{2} \mathrm{Cl}_{2}$, filtration of the dicyclohexylurea (DHU) side product, followed by purification over silica column using hexane/ethyl acetate solution.
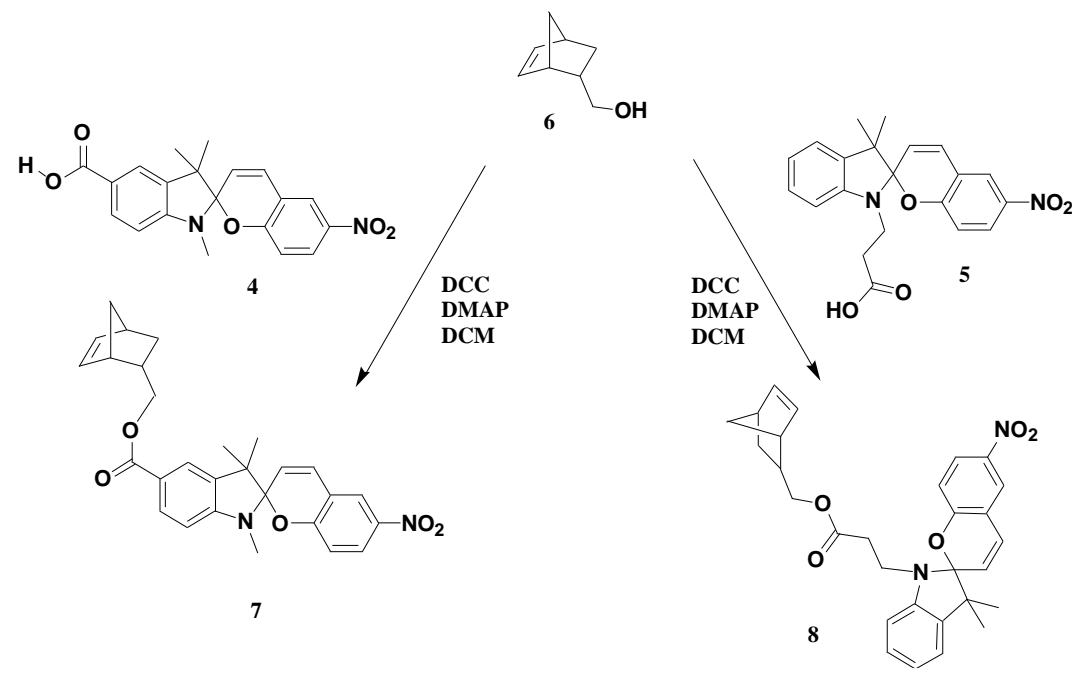

Scheme 2. Synthesis of norbornene monomer functionalized with spiropyran moieties.

The structural identity of the new monomeric units was accomplished using NMR spectroscopic analysis. For example, the carboxylic resonance at $12.38 \mathrm{ppm}$ of spiropyran 4 disappeared from the corresponding monomer 7 due to the formation of the ester link. Also, the methylene protons of compound 5 was shifted further upfield upon esterification. Meanwhile, the presence of the new resonances of the norbornene moiety was observed. Since norbornene molecules exist as a mixture of their exo and endo isomers, their identity has been confirmed using two-dimensional (2D)-NMR spectroscopy. Identification of the endo isomer begins with the assignment of its olefinic protons, $\mathrm{H}_{6}$ and $\mathrm{H}_{5}$. These protons revealed strong coupling with each other and were assigned to the resonance in 
the range of 5.89-5.91 and 6.01-6.06 ppm for $\mathrm{H}_{6}$ and $\mathrm{H}_{5}$, respectively. The bridgehead protons, $\mathrm{H}_{1}$ and $\mathrm{H}_{4}$, were then recognized based on their correlations with the olefinic protons. $\mathrm{H}_{1}$ appeared between 3.39-3.49 ppm \& 3.51-3.56 ppm for monomers 7 and 8, respectively. Whereas $\mathrm{H}_{4}$ was found slightly upfield at 2.83-2.95 ppm for monomer 7 and at 2.84 for monomer 8 . The exclusive coupling of $\mathrm{H}_{1}$ and $\mathrm{H}_{2}$ in the endo isomer indicated that the broad singlet at 2.14 and $2.15 \mathrm{ppm}$ is corresponding to $\mathrm{H}_{2} \mathrm{n}$ of monomer 7 and 8, respectively. This assignment was verified based on the connectivity of the $\mathrm{H}_{2}$ resonance, with two peaks appearing further upfield in the spectrum in the range of $0.36-0.54$ and 1.1.66-1.1.83 ppm, which represent the $\mathrm{H}_{3 x}$ and the $\mathrm{H}_{3 n}$, respectively. The bridge protons, $\mathrm{H}_{7 \mathrm{a}}$ and $\mathrm{H}_{7 \mathrm{~s}}$, also exhibited strong coupling with each other and resonated as multiplets between 1.11-1.44 ppm $\left(\mathrm{H}_{7 \mathrm{a}}\right)$ and $1.66-1.83 \mathrm{ppm}\left(\mathrm{H}_{7 \mathrm{~s}}\right)$.

The exo isomeric protons were identified using a similar stepwise strategy. The olefinic protons $\mathrm{H}_{6}$ and $\mathrm{H}_{5}$ appeared within the multiplet between 5.96-5.97 and 6.01-6.16 ppm for both isomers, while their characteristic couplings with the two bridgehead protons were then used to assign $\mathrm{H}_{1}$ to the multiplet in the range of $3.26-3.30 \mathrm{ppm}$ and $\mathrm{H}_{4}$ to the broad singlet appearing between 3.10 and $3.16 \mathrm{ppm}$. In contrast to the endo isomer, $\mathrm{H}_{2}$ in the exo isomer does not have any connectivity with $\mathrm{H}_{1}[77,78]$, while the determination of this proton was based on its coupling with the two $\mathrm{H}_{3}$ protons, it was assigned to the multiplet between 1.66 and $1.83 \mathrm{ppm} . \mathrm{H}_{3 \mathrm{x}}(\mathrm{m}, \delta 1.11-1.44 \mathrm{ppm})$ was identified via its coupling with the bridgehead proton $\mathrm{H}_{4}$, however this coupling could not be observed with $\mathrm{H}_{3 \mathrm{n}}[77,78]$. Finally, both $\mathrm{H}_{7}$ protons were assigned to the multiplet between 1.11 and $1.44 \mathrm{ppm}$.

\subsection{ROMP and Thermal Analysis}

Polymerization of the new monomeric units, 7 and 8 , was achieved via ring opening metathesis polymerization (ROMP) using Grubbs' catalyst. The reactions were performed using monomer/initiator ratio 100/1 over a period of $2 \mathrm{~h}$. The resulting polymers precipitated from the dichloromethane solution during this time, and the reactions were terminated on the addition of ethyl vinyl ether, Scheme 3.

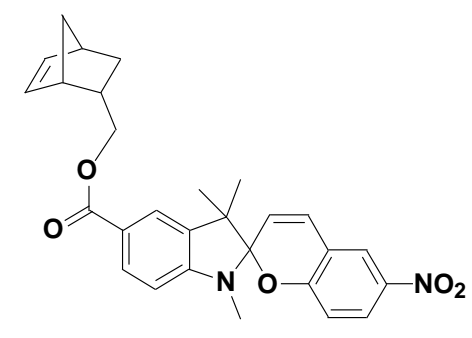

7

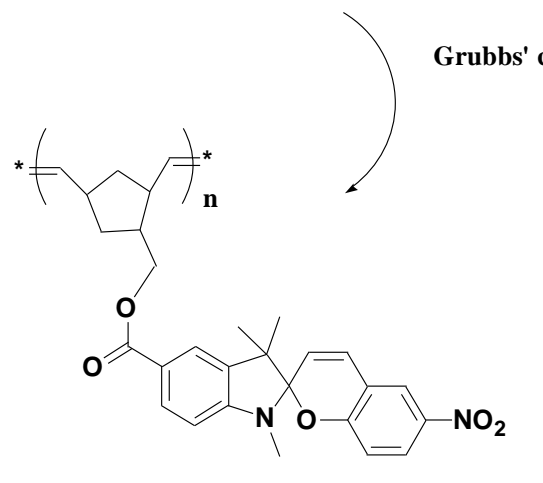

9
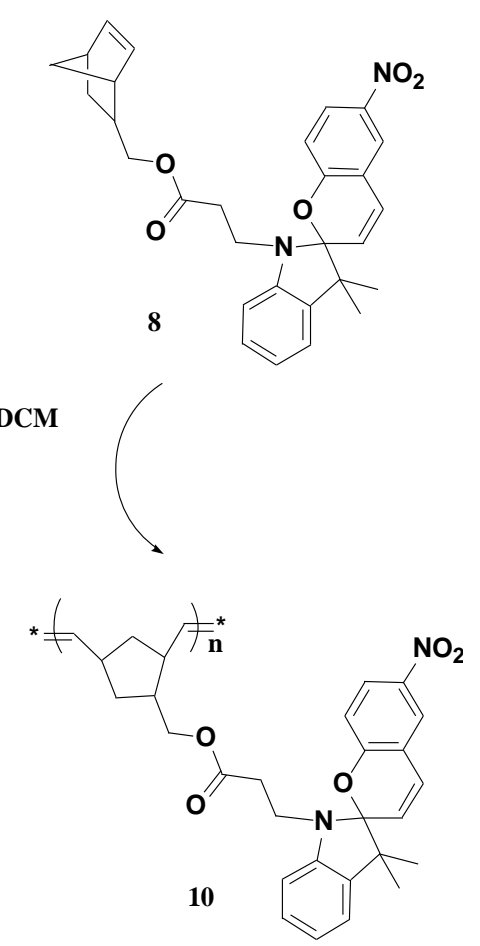

Scheme 3. Ring opening metathesis polymerization (ROMP) of norbornene monomer functionalized with spiropyran moieties. 
The new polymers were isolated as plastic sheets, which were completely insoluble in common organic solvents such as chloroform, dichloromethane, acetone, dimethylformamide, and dimethyl sulfoxide. The insolubility of these materials could be attributed to their high molecular weights along with the use of the low ratio of the initiator. The thermal behavior of the desired polymeric materials was performed using thermal gravimetric analysis (TGA) and differential scanning calorimetry (DSC). The TGA thermograms of polymers $\mathbf{9}$ and $\mathbf{1 0}$ revealed two distinctive weight losses. The first weight loss is between 400 and $447^{\circ} \mathrm{C}$, and is attributed to the partial decomposition of the pendent spiropyran motifs with degradation of the polymer backbone, while the second weight loss is between 530 and $600{ }^{\circ} \mathrm{C}$ and is corresponding to the degradation of the remaining polymeric chains.

The glass transition temperature of the new polymers was investigated using DSC measurements. It is well known that polynorbornene is a rather flexible chain, arising from its low $T_{\mathrm{g}}$ value $[79,80]$. This value can be manipulated via incorporation of different molecules into the side chain of the polymers [46-62]. Therefore, it is anticipated that the functionalization of norbornene monomers with the spiropyran moieties increases the $T_{\mathrm{g}}$ values of their corresponding polymers. The DSC thermograms of polymers 9 and 10 exhibits a $T_{g}$ value of $136^{\circ} \mathrm{C}$ and $127^{\circ} \mathrm{C}$, respectively. Figure 1 is representative examples of TGA, DSC thermograms, and FT-IR analysis.
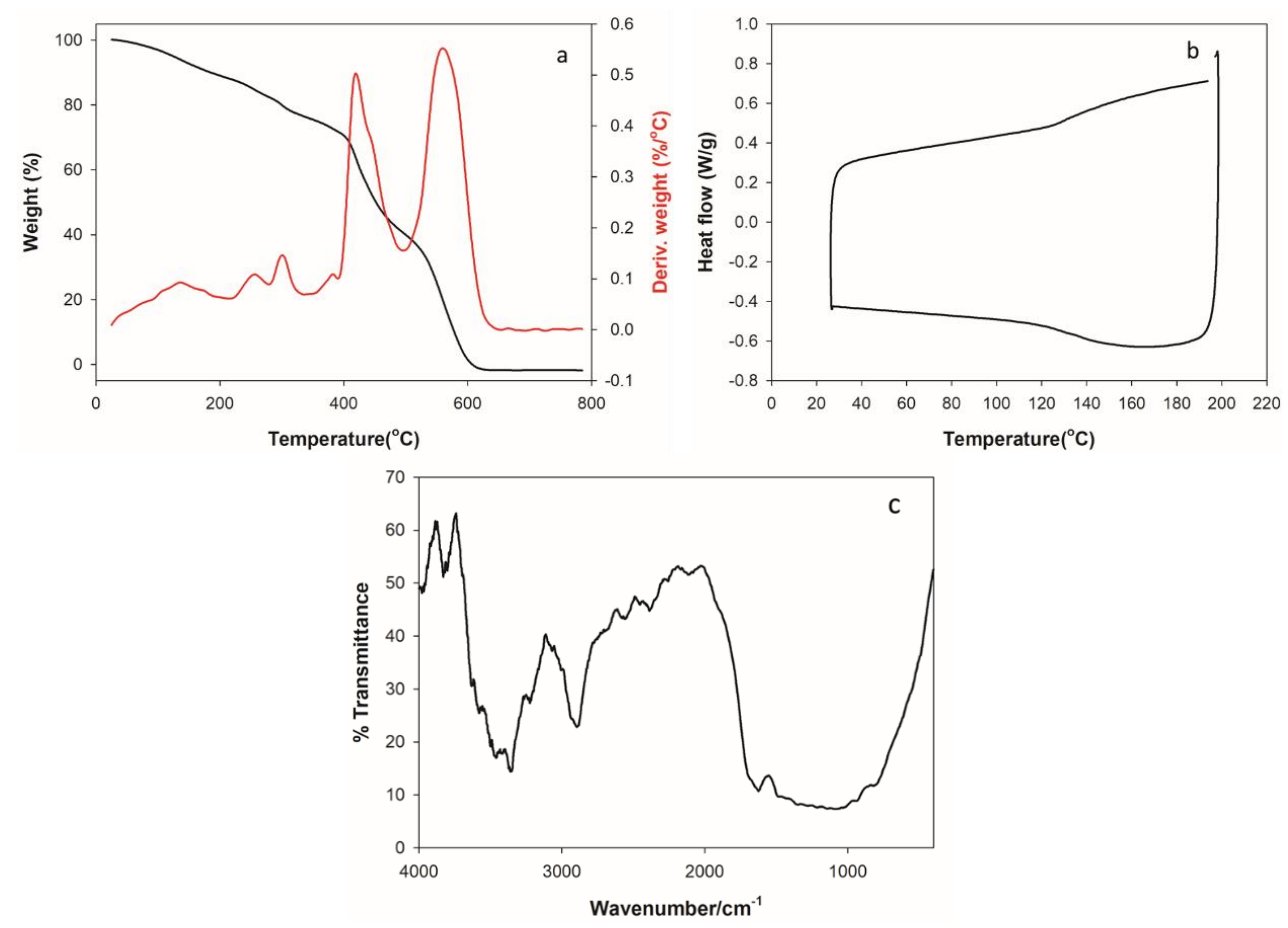

Figure 1. Thermogravimetric analysis (TGA) thermogram (a) and Differential Scanning Calorimeter (DSC) thermogram (b) and fourier transform infrared spectroscopy (FT-IR) spectrum (c) of polymer $\mathbf{9}$.

\subsection{Thermochromic Behavior}

The prepared polymers displayed a reversible thermochromic behavior upon being exposed to heat either as a dry or wet solid sheet. The wettability was tested against humidity and in various organic solvents, such as dichloromethane, dimethyl formamide, methanol, and chloroform. Unlike some thermochromic systems [81], the new polymers displayed excellent thermochromic performance either as a dry or wet sheet. In general, this behavior corresponds to the transition process of the spiroheterocyclic moiety in the polymer side chain to the quasi-planar open merocyanine. The colored merocyanine form has been known for its strong tendency to associate into aggregates with a stack-like arrangement of the merocyanine molecules [82]. This behavior is triggered by the high concentration of the spiropyran molecules and manipulates their optical response $[83,84]$. The molecular dipole 
arrangement of the merocyanine usually takes place in two different styles, H-aggregates that are responsible for the production of the hypthochromic shift in the absorption band, while the J-aggregates produces the bathochromic shift in the absorption band [83,84].

Figure 2 illustrates the influence of temperature on the polymer optical response. Upon exposure to heat, the color of the polymeric materials changed from reddish orange color into dark gray. This color range is attributed to the conformation of the spiropyran into the zwitrionic merocyanine form that is associated with bathochromic shift due to the presence of the J-aggregates.

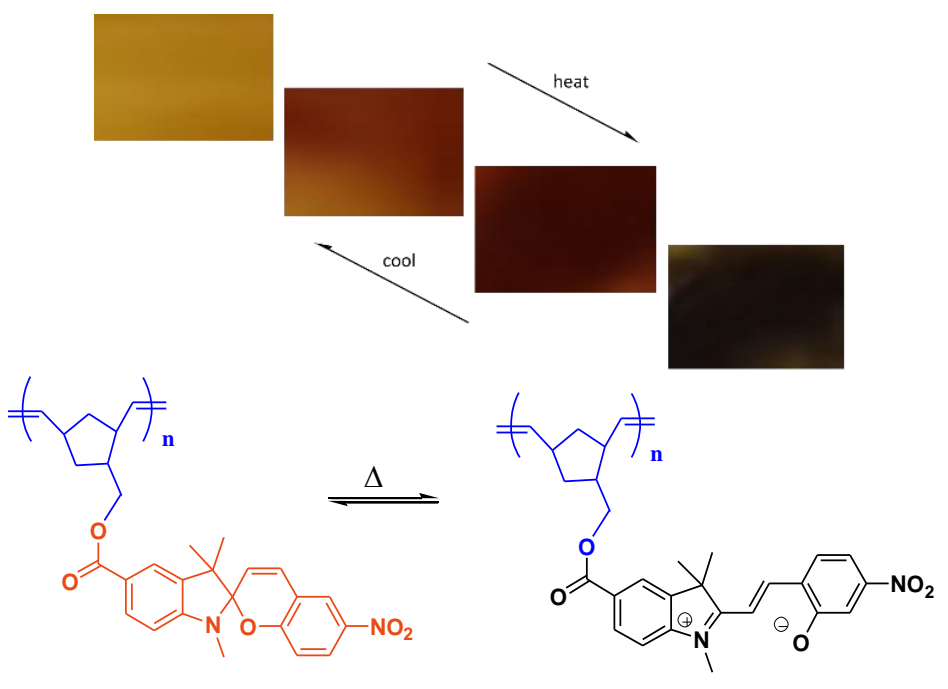

Figure 2. Thermochromic behavior of polymer 9 .

\subsection{Plasma Treatment and X-ray Diffraction}

The surface properties of polymers are utilized for their possible applications, however these properties in most cases do not meet the required purposes. Tailoring the surface properties of the polymeric materials has been the focus of many studies [72-75]. One of the successful techniques that has been used to achieve this goal is the plasma treatment, which provides morphological changes to these materials [72-75]. Properties such as scratch-resistance, wettability, biocompatibility, gas transmission, adhesion, and friction could be optimized using different types of plasma systems, and afford great opportunities to suit the desired applications [72-75]. For example, Neves' group reported the treatment of electrospun polycaprolactone nanofiber meshes (NFMs) by radio-frequency (RF) plasma containing $\left(\mathrm{Ar}\right.$ or $\left.\mathrm{O}_{2}\right)$. This technique allowed for the improvement of the surface hydrophilicity through forming oxygen containing groups at the surface of the polymer, which enhanced their biological performance, such as adhesion and proliferation over three model cell lines, fibroblasts, chondrocytes, and osteoblasts [73].

In this study, the surface of the new polymers was examined using scanning electron microscope (SEM) in order to study its morphology. As anticipated, polynorbornene containing spiropyran molecules are distinguished by their highly porous and amorphous surface, as seen in Figure 3. Modification of the surface character has been achieved using atmospheric pressure air Dielectric Barrier Discharge (DBD) plasma treatment at different periods of time; the surface has been exposed to the plasma system for two, five, and ten minutes. The interaction with the surface was carried out using sinusoidal waveform signal of $23 \mathrm{kV}$ and $25 \mathrm{kHz}$ and its effect on the surface characteristic has been monitored via SEM images. As can be seen in Figures 4 and 5, the porosity of the polymers has been reduced upon the plasma treatment. Moreover, with increasing the time period of the treatment, some surface areas have been changed to be completely nonporous. Other regions exhibited highly ordered thread-like structures that could be attributed to the J-aggregates of the merocyanine form [85]. 
These surface changes could broaden the applications of this class of materials into areas such as non-porous membranes for reverse osmosis, nanofiltration, or molecular separation in the gas phase.
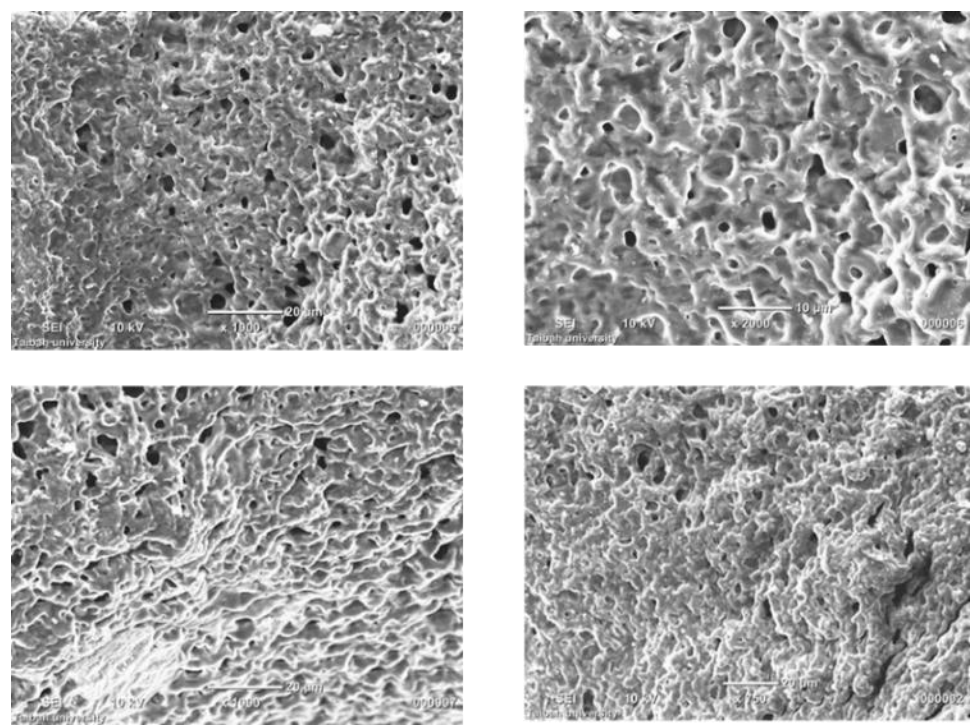

Figure 3. Scanning Electron Microscope (SEM) of polynorbornene containing spiropyran 9.
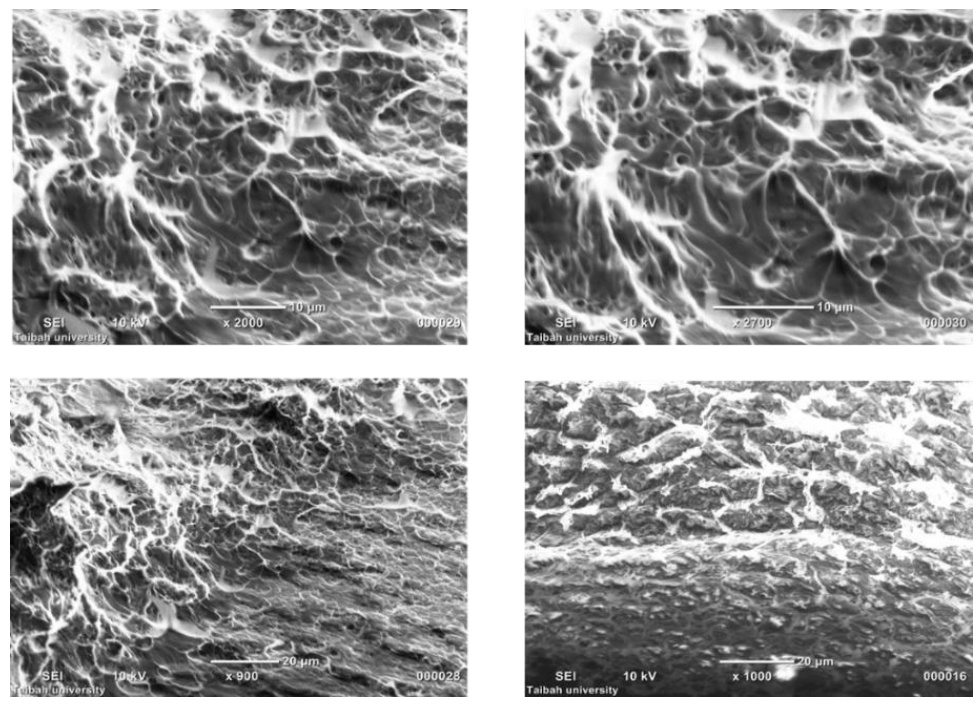

Figure 4. SEM of polynorbornene pendent spiropyran 9. (After plasma treatment for $2 \mathrm{~min}$ (top) and 5 min (bottom)).
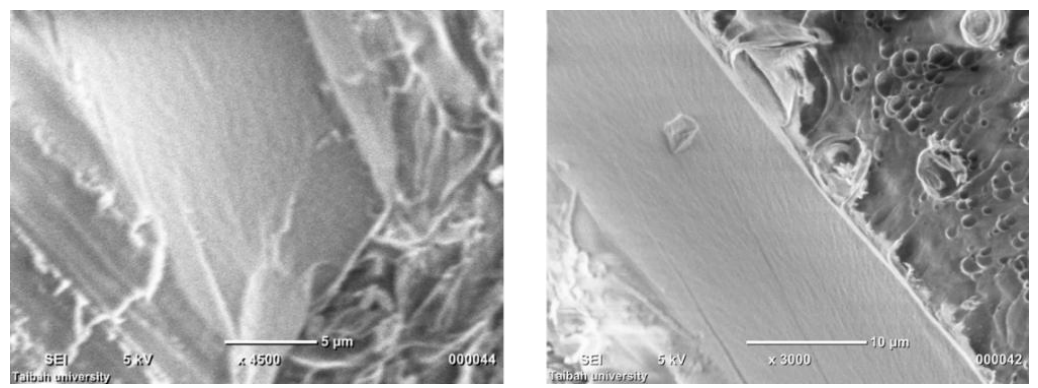

Figure 5. SEM of polynorbornene pendent spiropyran 9. (After plasma treatment for $10 \mathrm{~min}$ ). 
The X-ray diffraction of spiropyran containing polynorbornenes confirms the amorphous nature of the polymer, as seen in Figure 6a [86]. Moreover, the presence of the broad halo refers to the low stereoregularity of the polymer segments. The pattern shows a number of Bragg reflections, which can be indexed on the bases of the face centered cubic (FCC) structure of ruthenium. The diffraction peaks obtained at $2 \theta=38.6,44,64.5$, and $77.6^{\prime \prime}$ are identical with those reported for the standard ruthenium metal, which indicates the presence of some traces of ruthenium catalyst that have been trapped in the polymer matrix. Meanwhile, the interlayer spacing of polymer 9 (Figure 6a) can be calculated using the defined peak at $2 \theta=18.5^{\circ}$ that is according to Bragg's equation (with $\lambda=1.54 \AA$ ) and corresponds to $\mathrm{d}=7.9 \AA$.

Figure $6 \mathrm{~b}$ illustrates the diffraction patterns of polymer 9 after being exposed to the atmospheric pressure air Dielectric Barrier Discharge (DBD) plasma. As we mentioned previously, the treatment of the polymer surface with the DBD system has been tested at different periods of time. XRD comparison between the untreated sample and the treated ones (Figure 6c) showed that the width of the broad halo decreases with the increase of the treatment time. This could be attributed to the highly ordered J-aggregates of the merocyanine form in thread like-structures as a result of DBD plasma operating sinusoidal high voltage [85]. This hypothesis is also supported by the SEM images, Figure 5. It is also important to mention that the broad halo peaks for the treated polymers were not shifted to higher $2 \theta$ values, which means that the structures of these polymers did not change after the plasma treatment.
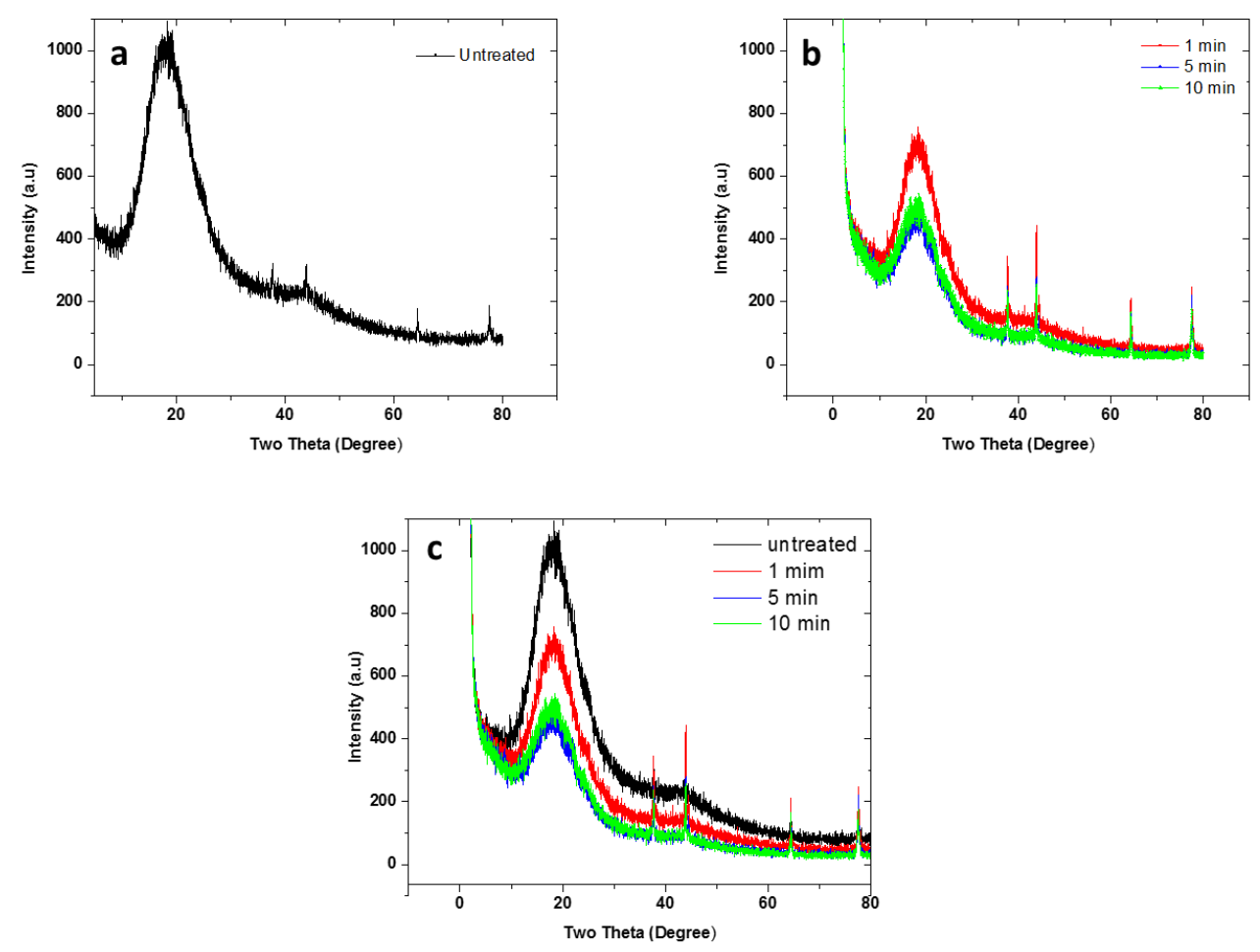

Figure 6. X-ray diffraction of polymer 9. (a) the untreated sample; (b) after being exposed to the atmospheric pressure air Dielectric Barrier Discharge (DBD) plasma; (c) the untreated sample and the treated ones.

\section{Conclusions}

Chromogenic polymers hold a special place due to their potential applications in various fields, such as optical devices, data storage, and switches. This research work illustrates a successful attempt to functionalize norbornene monomers with spiropyran moieties to tailor the properties of their corresponding polymer. Successful ring opening metathesis polymerization of the new monomers allowed for the isolation of polynorbernene pendent spiropyran moieties. The new polymers displayed 
reversible thermochromic ability due to the conversion of the closed spiropyran moiety to the open merocyanine form that is associated with bathochromic shift due to the presence of the J-aggregates. In the meantime, the obtained polymers exhibited an amorphous nature with a high porosity. This texture enhances the thermochromic ability of the polymers due to the presence of the leuco dyes, as well as their nematic nature. Treatment of the obtained polymers with atmospheric pressure air Dielectric Barrier Discharge (DBD) plasma changes the porosity of the surface, which make this class of polymer eligible for various applications, such as non-porous membranes for reverse osmosis, nanofiltration, or molecular separation in the gas phase.

Acknowledgments: The Authors are highly indebted to King Abdel-Aziz City for Science and Technology (KACST) for fully financial support of this work through the project number MS-34-95. Saleh A. Ahmed is highly indebted to Alexander von Humboldt Foundation (A.v.H.) and Jochen Mattay, Bielefeld University, Germany for helping with some analytical and spectroscopic measurements.

Author Contributions: Saleh A. Ahmed, Rawda M. Okasha, Khalid S. Khairou conceived and designed the experiments; Saleh A. Ahmed, Rawda M. Okasha, Khalid S. Khairou performed the experiments; Saleh A. Ahmed, Rawda M. Okasha, Khalid S. Khairou analyzed the data and wrote the paper. Saleh A. Ahmed, Rawda M. Okasha, Khalid S. Khairou, Tarek H. Afifi, Abdel-Aleam H. Mohamed and Alaa S. Abd-El-Aziz discussed the results and commented on the manuscript.

Conflicts of Interest: The authors declare no conflict of interest.

\section{References}

1. Seeboth, A.; Ruhmann, R.; Mühling, O. Thermotropic and Thermochromic Polymer Based Materials for Adaptive Solar Control. Materials 2010, 3, 5143-5168. [CrossRef] [PubMed]

2. Hebbard, C.F.F.; Wang, Y.; Baker, C.J.; Morrissey, J.H. Synthesis and Evaluation of Chromogenic and Fluorogenic Substrates for High-Throughput Detection of Enzymes That Hydrolyze Inorganic Polyphosphate. Biomacromolecules 2014, 15, 3190-3196. [CrossRef] [PubMed]

3. Garc'ia, J.M.; Garc'ia, F.C.; Serna, F.; De lapena, J.L. Fluorogenic and Chromogenic Polymer Chemosensors. Polym. Rev. 2011, 51, 341-390. [CrossRef]

4. Bamfield, P.; Hutchings, M.G. Chromic Phenomena: Technological Applications of Colour Chemistry, 2nd ed.; The Royal Society of Chemistry: Cambridge, UK, 2010; Chapter 1.3.

5. Mukherjee, S.; Boudouris, B.W. Design of a three-state switchable chromogenic radical-based moiety and its translation to molecular logic systems. Mol. Syst. Des. Eng. 2017, 2, 159-164. [CrossRef]

6. Pucci, A.; Bizzarri, R.; Ruggeri, G. Polymer composites with smart optical properties. Soft Mater. 2011, 7, 3689-3700. [CrossRef]

7. MacLaren, D.C.; White, M.A. Competition between dye-developer and solvent-developer interactions in a reversible thermochromic system. J. Mater. Chem. 2003, 13, 1701-1704. [CrossRef]

8. Luthern, J.; Peredes, A. Determination of the stoichiometry of a thermochromic color complex via Job's method. J. Mater. Sci. Lett. 2000, 19, 185-188. [CrossRef]

9. Seeboth, A.; Lötzsch, D.; Ruhmann, R.; Muehling, O. Thermochromic Polymers-Function by Design. Chem. Rev. 2014, 114, 3037-3068. [CrossRef] [PubMed]

10. Minkin, V.I. Photo-, Thermo-, Solvato-, and Electrochromic Spiroheterocyclic Compounds. Chem. Rev. 2004, 104, 2751-2776. [CrossRef] [PubMed]

11. Raymo, F.M.; Giordani, S. Signal Processing at the Molecular Level. J. Am. Chem. Soc. 2001, 123, 4651-4652. [CrossRef] [PubMed]

12. Wojtyk, J.T.C.; Wasey, A.; Xiao, N.N.; Kazmaier, P.M.; Hoz, S.; Yu, C.; Lemieux, R.P.; Buncel, E. Elucidating the Mechanisms of Acidochromic Spiropyran-Merocyanine Interconversion. J. Phys. Chem. A 2007, 111, 2511-2516. [CrossRef] [PubMed]

13. Keum, S.R.; Lee, K.B.; Kazmaier, P.M.; Buncel, E. A novel method for measurement of the merocyanine-spiropyran interconversion in non-activated 1,3,3-trimethylspiro-(2H-1-benzopyran-2,2'-indoline) derivatives. Tetrahedron Lett. 1994, 35, 1015-1018. [CrossRef]

14. Rosario, R.; Gust, D.; Hayes, M.; Jahnke, F.; Springer, J.; Garcia, A.A. Photon-Modulated Wettability Changes on Spiropyran-Coated Surfaces. Langmuir 2002, 18, 8062-8069. [CrossRef] 
15. Wagner, K.; Byrne, R.; Zanoni, M.; Gambhir, S.; Dennany, L.; Breukers, R.; Higgins, M.; Wagner, P.; Diamond, D.; Wallace, G.G.; et al. A Multiswitchable Poly(terthiophene) Bearing a Spiropyran Functionality: Understanding Photo- and Electrochemical Control. J. Am. Chem. Soc. 2011, 133, 5453-5462. [CrossRef] [PubMed]

16. Lenoble, C.; Becker, R.S. Photophysics, photochemistry, kinetics, and mechanism of the photochromism of 6'-nitroindolinospiropyran. J. Phys. Chem. 1986, 90, 62-65. [CrossRef]

17. Parthenopoulos, D.A.; Rentzepis, P.M. Three-Dimensional Optical Storage Memory. Science 1989, 245, 843-845. [CrossRef] [PubMed]

18. Tipikin, D.S. Mechanochromism of Organic compounds by The Example of Spiropyran. Russ. J. Phys. Chem. 2001, 75, 1720-1722.

19. Hauser, L.; Knall, A.C.; Roth, M.; Trimmel, G.; Edler, M.; Griesser, T.; Kern, W. Reversible photochromism of polynorbornenes bearing spiropyran side groups. Monatsh. Chem. 2012, 143, 1551-1558. [CrossRef] [PubMed]

20. Keum, S.R.; Ahn, S.M.; Roh, S.J.; Ma, S.Y. The synthesis and spectroscopic properties of novel, photochromic indolinobenzospiropyran-based homopolymers prepared via ring-opening metathesis polymerization. Dyes Pigments 2010, 86, 74-80. [CrossRef]

21. Mistry, B.B.; Patel, R.G.; Patel, V.S. Synthesis and characterization of photochromic homopolymer/copolymer. J. Appl. Polym. Sci. 1997, 64, 841-848. [CrossRef]

22. Verborgt, J.; Smets, G. Photochromic behavior of copolymers of indolinospirobenzopyrane methacrylic derivatives. J. Polym. Sci. Polym. Chem. Ed. 1974, 12, 2511-2523. [CrossRef]

23. Su, J.H.; Chen, J.; Zeng, F.; Chen, Q.M.; Wu, S.Z.; Tong, Z. Synthesis and photochromic property of nanoparticles with spiropyran moieties via one-step miniemulsion polymerization. Polym. Bull. 2008, 61, 425-434. [CrossRef]

24. Moniruzzaman, M.; Fernando, G.F.; Bellamy, A.J. Synthesis and structural investigation of $1^{\prime}, 3^{\prime}, 3^{\prime}$-trimethyl6-hydroxy-spiro(2H-1-benzopyran-2,2'-indoline), 1',3',3'-trimethyl-6-methacryloyloxy-spiro(2H-1-benzopyran$2,2^{\prime}$-indoline) and a copolymer with methyl methacrylate by 1D and 2D NMR spectroscopy. Eur. Polym. J. 2006, 42, 1455-1466. [CrossRef]

25. Choi, Y.K.; Kim, E.Y.; Keum, S.R. Synthesis and polymerization of 6-(alkyloxyphenyl)carbonyl substituted spirobenzopyran. Tetrahedron Lett. 1998, 39, 8861-8864. [CrossRef]

26. Schenderlein, H.; Voss, A.; Stark, R.W.; Biesalski, M. Preparation and Characterization of Light-Switchable Polymer Networks Attached to Solid Substrates. Langmuir 2013, 29, 4525-4534. [CrossRef] [PubMed]

27. Negishi, N.; Tsunemitsu, K.; Ishihara, K.; Shinohara, I.; Okano, T.; Kataoka, K.; Akaike, T.; Sakurai, Y. Photo Induced reversible change on wettability on photochromic polymer surface. Kobunshi Ronbunshu 1980, 37, 287-291. [CrossRef]

28. Nakao, R.; Ueda, N.; Abe, Y.; Horii, T.; Inoue, E. New photochromic inorganic/organic hybrid siloxane gels with chemically bonded spirobenzopyran moiety. Polym. Adv. Technol. 1994, 5, 240-241. [CrossRef]

29. Nakao, R.; Ueda, N.; Abe, Y.; Horii, T.; Inoue, E. Preparation and photochromic properties of oligomeric poly(dimethylsiloxane) with the spiropyran or spirooxazine moiety in the side chain. Polym. Adv. Technol. 1995, 6, 243-247. [CrossRef]

30. Nakao, R.; Ueda, N.; Abe, Y.; Horii, T.; Inoue, H. Polymeric siloxanes with a substituent and the spirobenzopyran moiety: Effect of polar substituent on the photochromic properties. Polym. Adv. Technol. 1996, 7, 863-866. [CrossRef]

31. Kim, J.H.; Ban, S.Y.; Zhang, Q.; Kim, G.W.; Cho, M.J.; Choi, D.H. Effect of Photocrosslinking on Photochromism of Chalcone-based Polymeric Materials bearing Spiropyran Dye. Mol. Cryst. Liq. Cryst. 2006, 445, 307-314. [CrossRef]

32. Achilleos, D.S.; Vamvakaki, M. Multiresponsive Spiropyran-Based Copolymers Synthesized by Atom Transfer Radical Polymerization. Macromolecules 2010, 43, 7073-7081. [CrossRef]

33. Chen, J.; Zeng, F.; Wu, S.Z.; Zhao, J.Q.; Chen, Q.M.; Tong, Z. Reversible fluorescence modulation through energy transfer with $\mathrm{ABC}$ triblock copolymer micelles as scaffolds. Chem. Commun. 2008, 5580-5582. [CrossRef] [PubMed]

34. Lee, H.I.; Wu, W.; Oh, J.K.; Mueller, L.; Sherwood, G.; Peteanu, L.; Kowalewski, T.; Matyjaszewski, K. Light-Induced Reversible Formation of Polymeric Micelles. Angew. Chem. Inter. Ed. 2007, 46, 2453-2457. [CrossRef] [PubMed] 
35. Huang, C.Q.; Wang, Y.; Hong, C.Y.; Pan, C.Y. Spiropyran-Based Polymeric Vesicles: Preparation and Photochromic Properties. Macromol. Rapid Commun. 2011, 32, 1174-1179. [CrossRef] [PubMed]

36. Li, C.H.; Zhang, Y.X.; Hu, J.M.; Cheng, J.J.; Liu, S.Y. Reversible Three-State Switching of Multicolor Fluorescence Emission by Multiple Stimuli Modulated FRET Processes within Thermoresponsive Polymeric Micelles. Angew. Chem. Int. Ed. 2010, 49, 5120-5124. [CrossRef] [PubMed]

37. Guragain, S.; Bastakoti, B.P.; Ito, M.; Yusa, S.-I.; Nakashima, K. Aqueous polymeric micelles of poly[ $N$-isopropylacrylamide- $b$-sodium 2-(acrylamido)-2-methylpropanesulfonate] with a spiropyran dimer pendant: Quadruple stimuli-responsiveness. Soft Matter 2012, 8, 9628-9634. [CrossRef]

38. Chung, D.J.; Ito, Y.; Imanishi, Y. Preparation of porous membranes grafted with poly(spiropyran-containing methacrylate) and photocontrol of permeability. J. Appl. Polym. Sci. 1994, 51, 2027-2033. [CrossRef]

39. Bardavid, Y.; Goykhman, I.; Nozaki, D.; Cuniberti, G.; Yitzchaik, S. Dipole Assisted Photogated Switch in Spiropyran Grafted Polyaniline Nanowires. J. Phys. Chem. C 2011, 115, 3123-3128. [CrossRef]

40. Moniruzzaman, M.; Sabey, C.J.; Fernando, G.F. Photoresponsive polymers: An investigation of their photoinduced temperature changes during photoviscosity measurements. Polymer 2007, 48, 255-263. [CrossRef]

41. Connal, L.A.; Franks, G.V.; Qiao, G.G. Photochromic, Metal-Absorbing Honeycomb Structures. Langmuir 2010, 26, 10397-10400. [CrossRef] [PubMed]

42. Wu, S.Z.; Lu, J.R.; Zeng, F.; Chen, Y.N.; Tong, Z. Photoinduced Formation of Microscopic Ordering and Macroscopic Pattern in Spiropyran-Containing Polyacrylate-Tetraoctylammonium Bromide Films. Macromolecules 2007, 40, 5060-5066. [CrossRef]

43. Ratner, J.; Kahana, N.; Warshawsky, A.; Krongauz, V. Photochromic Polysulfones. 2. Photochromic Properties of Polymeric Polysulfone Carrying Pendant Spiropyran and Spirooxazine Groups. Ind. Eng. Chem. Res. 1996, 35, 1307-1315. [CrossRef]

44. Warshawsky, A.; Kahana, N.; Buchholtz, F.; Zelichonok, A.; Ratner, J.; Krongauz, V. Photochromic Polysulfones. 1. Synthesis of Polymeric Polysulfone Carrying Pendant Spiropyran and Spirooxazine Groups. Ind. Eng. Chem. Res. 1995, 34, 2825-2832. [CrossRef]

45. Allcock, H.R.; Kim, C. Photochromic polyphosphazenes with spiropyran units. Macromolecules 1991, 24, 2846-2851. [CrossRef]

46. Ivin, K.J.; Mol, J.C. Olefin Metathesis and Metathesis Polymerization; Academic Press: San Diego, CA, USA, 1997.

47. Dragutan, V.; Streck, R. Catalytic Polymerization of Cycloolefins: Ionic, Ziegler-Natta and Ring-Opening Metathesis Polymerization; Elsevier: Amsterdam, The Netherlands, 2000.

48. Trnka, T.M.; Grubbs, R.H. The Development of $\mathrm{L}_{2} \mathrm{X}_{2} \mathrm{Ru}=\mathrm{CHR}$ Olefin Metathesis Catalysts: An Organometallic Success Story. Acc. Chem. Res. 2001, 34, 18-29. [CrossRef] [PubMed]

49. Buchmeiser, M.R. Homogeneous Metathesis Polymerization by Well-Defined Group VI and Group VIII Transition-Metal Alkylidenes: Fundamentals and Applications in the Preparation of Advanced Materials. Chem. Rev. 2000, 100, 1565-1604. [CrossRef] [PubMed]

50. Grubbs, R.H. Hand Book of Metathesis; Wiley-VCH: Weinhiem, Germany, 2003.

51. Schrocks, R.R. Multiple Metal-Carbon Bonds for Catalytic Metathesis Reactions (Nobel Lecture). Angew. Chem. Int. Ed. 2006, 45, 3748-3759. [CrossRef] [PubMed]

52. Grubbs, R.H. Olefin-Metathesis Catalysts for the Preparation of Molecules and Materials (Nobel Lecture). Angew. Chem. Int. Ed. 2006, 45, 3760. [CrossRef] [PubMed]

53. Bielawski, C.W.; Grubbs, R.H. Living ring-opening metathesis polymerization. Prog. Polym. Sci. 2007, 32, 1-29. [CrossRef]

54. Abd-El-Aziz, A.S.; Todd, E.K.; Okasha, R.M. Polymerization of Olefinic Monomers Functionalized with Cationic Cyclopentaienyliron Arene Complexes. In Macromolecules Containing Metal and Metal-Like Elements; Abd-El-Aziz, A., Carraher, C., Pittman, C., Sheats, J., Zeldin, M., Eds.; Wiley-Interscience, John Wiley and Sons, Inc.: New York, NY, USA, 2004; Volume 2, p. 233.

55. Abd-El-Aziz, A.S.; May, L.J.; Hurd, J.A.; Okasha, R.M. First Ring-Opening Metathesis Polymerization of Norbornenes Containing Cationic Iron Moieties. J. Polym. Sci. Part A Polym. Chem. 2001, 39, 2716-2722. [CrossRef]

56. Abd-El-Aziz, A.S.; Okasha, R.M.; May, L.J.; Hurd, J. Synthesis of norbornenes containing cationic mono- and di(cyclopentadienyliron)arene complexes and their ring-opening metathesis polymerization. J. Polym. Sci. Part A Polym. Chem. 2006, 44, 3053-3070. [CrossRef] 
57. Abd-El-Aziz, A.S.; Shipman, P.O.; Pilfold, J.L.; Shipley, P.R. Synthesis of Upper Rim Functionalized Calixarene-Based Poly(norbornenes). Macromol. Chem. Phys. 2010, 211, 996-1002. [CrossRef]

58. Abd-El-Aziz, A.S.; Shipman, P.O.; Shipley, P.R.; Boden, B.N.; Aly, S.; Harvey, P.D. Homo- and Co-Polymers of Norbornene containing Aryl- and Hetaryl-Azo Dyes; Synthesis and Sensing Properties. Macromol. Chem. Phys. 2009, 210, 2099-2106. [CrossRef]

59. Joraid, A.A.; Abu-Sehly, A.A.; Alamri, S.N.; Al-Raqa, S.Y.; Shipman, P.O.; Shipley, P.R.; Abd-El-Aziz, A.S. Kinetics analysis of degradation of polynorbornene containing aryl or hetaryl azo dye. Thermochim. Acta 2012, 529, 22-24. [CrossRef]

60. Joraid, A.A.; Alamri, S.N.; Abu-Sehly, A.A.; Al-Raqa, S.Y.; Shipman, P.O.; Shipley, P.R.; Abd-El-Aziz, A.S. Isothermal Kinetics and Thermal Degradation of an Aryl Azo Dye-containing Polynorbornene. Thermochim. Acta 2011, 515, 38-42. [CrossRef]

61. Okasha, R.M. Proton Sensing Color Changing Organoiron and Organic Macromolecules. J. Inorg. Organomet. Polym. Mater. 2015, 25, 354-366. [CrossRef]

62. Abd-El-Aziz, A.S.; Okasha, R.M.; Afifi, T.H.; Todd, E.K. A New Class of Cationic Organoiron Polynorbornenes Containing Azo Dyes. Macromol. Chem. Phys. 2003, 204, 555-563. [CrossRef]

63. Sallenave, X.; Delbaere, S.; Vermeersch, G.; Ahmed, S.A.; Pozzo, J.-L. Photoswitch based on remarkably simple naphthopyrans. Tetrahedron Lett. 2005, 46, 3257-3259. [CrossRef]

64. Sallenave, X.; Delbaere, S.; Ahmed, S.A.; Vermeersch, G.; Pozzo, J.-L. 5-Ureido-3,3-diphenyl-3Hnaphtho[2,1-b]pyrans: Photoswitchable self-assembling architectures. Int. J. Photoenergy 2004, 6, 169-173. [CrossRef]

65. Ahmed, S.A.; Tanaka, M.; Ando, H.; Tawa, K.; Kimura, K. Fluorescence emission control and switching of oxymethylcrowned spirobenzopyrans by metal ion. Tetrahedron 2004, 60, 6029-6036. [CrossRef]

66. Ahmed, S.A.; Tanaka, M.; Ando, H.; Iwamoto, H.; Kimura, K. Oxymethylcrowned chromene: photoswitchable stoichiometry of metal ion complex and ion-responsive photochromism. Tetrahedron 2004, 60, 3211-3220. [CrossRef]

67. El Guesmi, N.; Ahmed, S.A.; Maurel, F.; Althagafi, I.I.; Khairou, K.S. Photochromism of dihydroindolizines. Part XXII: Significant effect of region B substituents on tuning the photophysical properties of photochromic dihydroindolizines: Absorption, kinetic and computational studies. J. Photochem. Photobiol. A Chem. 2017, 348, 125-133. [CrossRef]

68. El Guesmi, N.; Ahmed, S.A.; Althagafi, I.I.; Khairou, K.S. Photochromism of Dihydroindolizines. Part XXI: Multiaddressable Photochromic Performances based on Pyrrolo[1,2-b]pyridazine photochromes: Kinetics, Substituent Effect and Solvatochromism. J. Photochem. Photobiol. A Chem. 2017, 346, 287-295. [CrossRef]

69. Ahmed, S.A.; El Guesmi, N.; Asghar, B.H.; Maurel, F.; Althagafi, I.I.; Khairou, K.S.; Muathen, H.A. Photochromism of dihydroindolizines Part XIX. Efficient one-pot solid-state synthesis, kinetic, and computational studies based on dihydroindolizine photochromes. J. Phys. Org. Chem. 2017, 30, e3614. [CrossRef]

70. Bagchi, D.; Ghosh, A.; Singh, P.; Dutta, S.; Polley, N.; Althagafi, I.I.; Jassas, R.S.; Ahmed, S.A.; Pal, S.K. Allosteric Inhibitory Molecular Recognition of a Photochromic Dye by a Digestive Enzyme: Dihydroindolizine makes $\alpha$-chymotrypsin Photo-responsive. Sci. Rep. (Nat.) 2016, 6, 1-11. [CrossRef] [PubMed]

71. Seeboth, A.; Lötzsch, D. Thermochromic Phenomena in Polymers; Smithers Rapra Technology Limited: Shrewsbury, UK, 2008.

72. Chen, W.; Menze, M.; Prucker, O.; Wang, E.; Ober, C.K.; Rühe, J. Morphology of Nanostructured Polymer Brushes Dependent on Production and Treatment. Macromolecules 2017, 50, 4715-4724. [CrossRef]

73. Martins, A.; Pinho, E.D.; Faria, S.; Pashkuleva, I.; Marques, A.P.; Reis, R.L.; Neves, N.M. Surface modification of electrospun polycaprolactone nanofiber meshes by plasma treatment to enhance biological performance. Small 2009, 5, 1195-1206. [CrossRef] [PubMed]

74. Gorjanc, M.; Mozetic, M. Modification of Fibrous Polymers by Gaseous Plasma: Principles, Techniques and Applications; Lambert Academic Publishing: Saarbrücken, Germany, 2014.

75. Kravets, L.; Dmitriev, S.; Dinescu, G.; Lazea, A.; Satulu, V. Effect of Plasma Treatment on Polymer Track Membranes. Plasma Process. Polym. 2009, 6, S796-S802. [CrossRef] 
76. El-Sayed, W.S.; Ouf, S.A.; Mohamed, A.-A.H. Deterioration to extinction of wastewater bacteria by non-thermal atmospheric pressure air plasma as assessed by $16 \mathrm{~S}$ rDNA-DGGE fingerprinting. Front. Microbiol. 2015, 6, 1098-1110. [CrossRef] [PubMed]

77. Musher, J.I. The N.M.R. Spectra of Some Bicyclo [2.2.1] Heptanol. Mol. Phys. 1963, 6, 93-100. [CrossRef]

78. Fisher, J.; Gradwell, M.J. Complete Assignment of the ${ }^{1} \mathrm{H}$ and ${ }^{13} \mathrm{C}$ NMR Spectra of Norbornene Derivatives. Magn. Reson. Chem. 1991, 29, 1068-1069. [CrossRef]

79. Ujihira, Y.; Li, H.-L.; Ito, K. Free volume study on three types of shape memory polymers by positron annihilation. Acta Phys. Polon. A 1999, 95, 677-682. [CrossRef]

80. Khosravi, E.; Szymanska-Buzar, T.S. (Eds.) Ring Opening Metathesis Polymerization and Related Chemistry: State of the Art and Visions for the New Century; Nato Science Series; Kluwer Academic Publishers: Dordrecht, The Netherlands, 2000; Volume 56, p. 140.

81. Dejong, S.J.; Broekhuis, M.D.; Byker, H.J. Constructions for Moisture Sensitive Thermochromic Layers and Structures Having Reduced Moisture Content in Thermochromic Layers. U.S. Patent 20140134367 A1, 17 January 2014.

82. Krongauz, V. Quasi-Crystals. Isr. J. Chem. 1979, 18, 304-311. [CrossRef]

83. Chang, J.; Lu, Y.; He, S.; Liu, C.; Zhao, L.; Zeng, X. Efficient fluorescent chemosensors for $\mathrm{HSO}_{4}{ }^{-}$based on a strategy of anion-induced rotation-displaced H-aggregates. Chem. Commun. 2013, 49, 6259-6261. [CrossRef] [PubMed]

84. Mçbius, D. Scheibe Aggregates. Adv. Mater. 1995, 7, 437-444. [CrossRef]

85. Berkovic, G.; Krongauz, V.; Weiss, V. Spiropyrans and Spirooxazines for Memories and Switches. Chem. Rev. 2000, 100, 1741-1753. [CrossRef] [PubMed]

86. Gao, H.; Zhang, J.; Chen, Y.; Zhu, F.; Wu, Q. Vinyl-polymerization of norbornene with novel anilido-imino nickel complexes/methylaluminoxane: Abnormal influence of polymerization temperature on molecular weight of polynorbornenes. J. Mol. Catal. A Chem. 2005, 240, 178-185. [CrossRef]

(C) 2017 by the authors. Licensee MDPI, Basel, Switzerland. This article is an open access article distributed under the terms and conditions of the Creative Commons Attribution (CC BY) license (http:/ / creativecommons.org/licenses/by/4.0/). 